\title{
Subsequent colic syndrome due to perirectal abscess in an equine model - Case report
}

\author{
[Síndrome cólica subsequente à abscesso perirretal em um equino - Relato de caso]
}

\section{"Case Report/Relato de Caso"}

\author{
Geórgia Camargo Góss ${ }^{1}$, Cláudia Medeiros Rodrigues ${ }^{2}$, Ricardo Pozzobon ${ }^{2}$, \\ Rafaela Silveira Prestes ${ }^{3}$, Inácio Manassi Conceição Brandolt ${ }^{1}$, Ingrid Rios Lima Machado ${ }^{1}$, \\ Brenda Strassburger Scheffel $^{1}$, Gustavo José Klaus ${ }^{1}$, Claudia Acosta Duarte ${ }^{1^{*}}$
}

\author{
${ }^{1}$ Departamento de Grandes Animais, Universidade Federal do Pampa, Uruguaiana-RS, Brasil. \\ ${ }^{2}$ Departamento de Grandes Animais, Universidade Federal de Santa Maria, Santa Maria-RS, Brasil. \\ ${ }^{3}$ Departamento de Diagnóstico por Imagem, Universidade Federal de Minas Gerais, Belo Horizonte-MG, Brasil. \\ *Autor para correspondência/Corresponding author: E-mail: caduarte74@gmail.com
}

\begin{abstract}
Colic is the most frequent syndrome of equine digestive system, and impaction is the most common disease among its many etiologies. The small colon can suffer with intraluminal or extraluminal obstructions resulting from many causes. These obstructions present signs such as abdominal pain, poorly altered physiological parameters, dyskinesia and tenesmus. The aim of the present study is to describe a small colon impaction secondary to perirectal abscess in the pelvic musculature. The equine model was assisted at Veterinary University Hospital of Federal University of Pampa (Unipampa) and surgery was the therapy of choice; however, the animal ended up dying during anesthesia application. The ultimate diagnostic was provided by necropsy, which showed one abscess in the pelvic musculature, close to the terminal portion of the rectum. The relevance of the present study lies on the importance of using complementary diagnostic methods, as well as on the presentation of another cause of colic, which is little described in the literature. The present results allowed enhancing the prognostics and treatments applied to horses with this disease.
\end{abstract}

Keywords: Colic; small colon; abscess; perirectal.

\begin{abstract}
Resumo
Cólica é uma das síndromes de maior ocorrência no sistema digestório de equino e, dentre as diversas etiologias, a compactação é a afecção mais comum. Quando se trata do cólon menor, as obstruções podem ser intraluminais ou extraluminais, sendo ocasionadas por diversas causas e apresentando-se com sinais de dor abdominal, parâmetros fisiológicos pouco alterados, disquesia e tenesmo. O objetivo deste trabalho foi descrever um caso de compactação de cólon menor secundário a um abscesso perirretal, localizado na musculatura pélvica. O equino foi atendido no Hospital Universitário Veterinário da Universidade Federal do Pampa (Unipampa), e após tratamento clínico optou-se pelo manejo cirúrgico. Entretanto o animal veio a óbito durante a indução anestésica o diagnóstico definitivo foi realizado na necropsia, durante a qual observou-se um abscesso na musculatura pélvica, próximo à porção final do reto. O presente relato tem relevância pois demonstra a importância da utilização de métodos complementares de diagnóstico além de apresentar uma causa de cólica pouco descrita na literatura, possibilitando melhorar o prognóstico e o tratamento de equinos acometidos por esta afecção.
\end{abstract}

Palavras-chave: Cólica; cólon menor; abscesso; perirretal.

\section{Introduction}

Impaction is one the most prevalent causes of colic in horses, assumingly, due to multifactorial reasons, and low quality feed stands out among them (Ferreira et al., 2009). Obstructions in the

small colon can be intraluminal or extraluminal. The extraluminal ones can be caused by lipomas, hernias, volvulus (Rakestraw and Hardy, 2006) and perirectal abscesses (Torkelson, 2002; Hunt and 
Pouke, 2008). The most common perirectal abscesses often result from bacterial contamination in previously injured tissues (Barber, 2008). This impaction type is similar to other obstructions observed in clinical frames, namely: dyschezia, tenesmus and few altered physiological parameters (Torkelson, 2002; Hunt and Pouke, 2008).

The aim of the present study was to describe small colon impaction secondary to perirectal abscess.

\section{Case Report}

A male criollo horse, approximately 14 months old, presenting body weight $300 \mathrm{~kg}$, with history of acute abdomen for 24 hours, was referred to the Veterinary University Hospital of Federal University of Pampa (Unipampa). The assessed model remained in natural pasture with other animals at the same age group. The model presented tachycardia and apathy during clinical examination; nasogastric intubation removed approximately $200 \mathrm{~mL}$ of gastric content. The veterinarian who referred the horse reported not to have performed transrectal palpation; however, it was not possible ensuring that the procedure was not conducted prior to the medical care provided at the hospital. The animal presented intensified pain on defecation. The Veterinarian also reported the administration of approximately $15 \mathrm{~L}$ of lactated ringer; analgesia was provided by intravenous administration of flunixin meglumine $(1.1 \mathrm{mg} / \mathrm{kg})$.

The horse showed abdominal bilateral distention, pain when moving, tenesmus, apathy and edema in the perianal region during the examination at the hospital (Figure 1), which showed moderate dehydration, congested oral mucosa, tachycardia and tachypnea, hyperthermia; abdominal auscultation evidenced decreased motility in all quadrants. Nasogastric intubation was performed and approximately $100 \mathrm{ml}$ of gastric content was removed, without any evidence of intestinal content. Transrectal palpation was not conducted due to the increased volume of the rectal wall, which also did not allow the hand of the examiner to enter. With one of the digits, it was noticed a temperature increase in the region and impacted content cranially to edema. Based on the technique by Busoni et al. (2011), abdominal ultrasonography was performed through the FLASH method at the veterinarian hospital where the animal was assisted. The images triggered the suspicion of increased fluid and moderate thickening of intestinal loops in the left dorsal colon, the small colon appeared to be affected. Besides enema, 30L of parenteral fluid therapy, based on lactated ringer solution associated with continuous lidocaine infusion $(0.05 \mathrm{mg} / \mathrm{Kg})$ administered through peripheral catheter introduced in the jugular vein, and with the administration of flunixin meglumine in the analgesic $(1.1 \mathrm{mg} / \mathrm{Kg})$ and antiendotoxic $(0.25$ $\mathrm{mg} / \mathrm{Kg}$ ) doses - approximately 5L of warm physiological solution was enough to dissolve the digitally palpated content - was performed. This procedure was conducted simultaneously to the general physical examination of the digestive system and to ultrasonography.

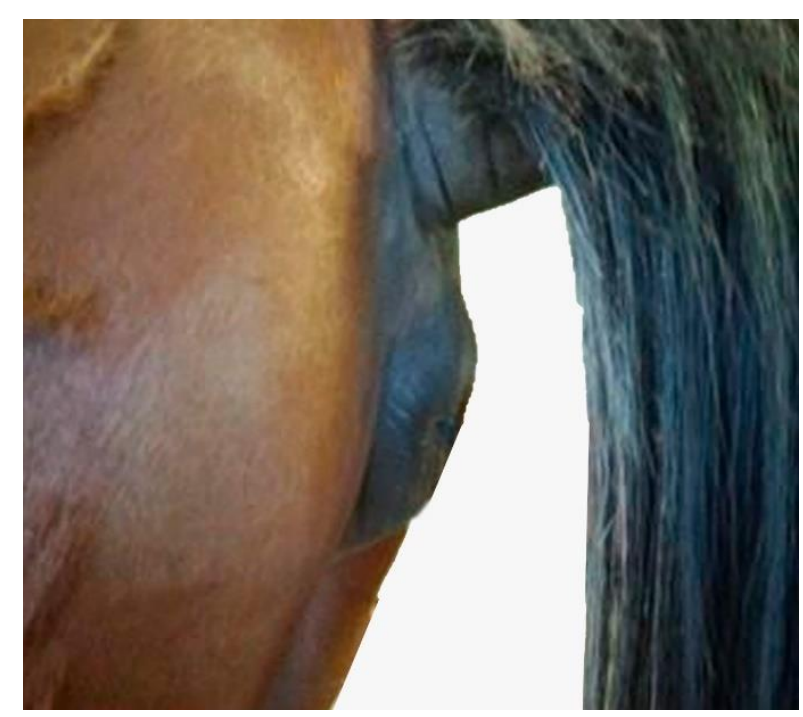

Figure 1. Photographic image highlighting the increased volume of the animal's anal region.

After the clinical therapy performed at the hospital, the general condition of the model improved: increased motility, release of gases and mimic defecation. These symptoms remained stable for approximately four hours; however, there was abdominal distention increase after this period, as well as uncontrollable pain, which demanded the conduction of an exploratory celiotomy. The animal presented cardiorespiratory arrest after anesthetic induction and ended up dying during the preoperative period.

The presence of impacted content in the small colon was confirmed during necropsy, which showed altered coloration and macroscopic evidences that the segment was not viable. There was one abscess (approximately $10 \mathrm{~cm} \mathrm{x} 7 \mathrm{~cm}$ ), at similar size of a tennis ball, in the perirectal region, next to the biceps femoris and semitendinosus muscle (Figure 2). Accordingly, the abscess was considered the primary cause of impaction in the herein described case. 


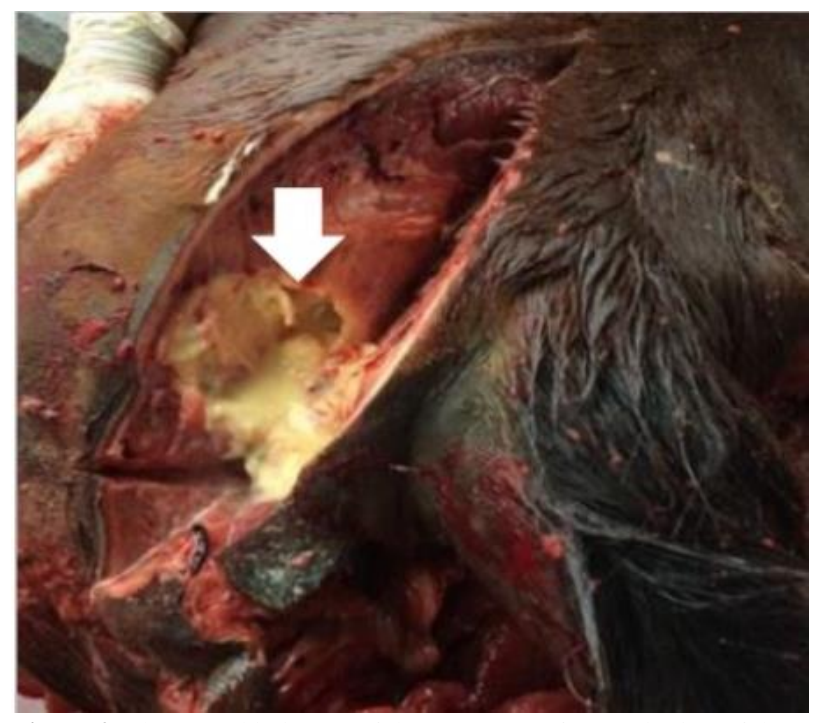

Figure 2. Photographic image of the necropsy, after sectioning of the pelvic musculature, when the perirectal abscess (white arrow) was observed.

\section{Discussion}

Colic syndrome events must be treated as emergency case and its diagnostic needs thorough clinical examination (Southwood, 2006) accompanied by complementary procedures to help defining the best prognostics and therapies (Cook and Hassel, 2014). Based on recommendations by Ferreira et al. (2009) to treat small colon diseases, the clinical approach consisted in fluid therapy, analgesia and enema. The option made for referring the horse to celiotomy resulted from the fast deterioration of the clinical frame and from the presence of uncontrollable pain (White et al., 2005).

According to Pascoe et al. (1983), similar to the present case report, horses face cardiorespiratory arrest after general anesthesia, mainly when their clinical condition is deteriorated. Anesthetic agents presenting depressant potential to the cardiac and respiratory systems can cause death episodes, which can be avoided by patient stabilization prior to the surgical procedure. However, emergency situations (as the herein described one) demand anesthesia, even at non-deal conditions, in order to rule out the primary cause of the clinical frame observed in the patient (Massone, 2011).

The perirectal abscess observed during the necropsy procedure was the cause of the small colon obstruction and impaction described in the present case report, since it was located at the terminal portion of the rectum. Such location justifies the formation of edema and the higher temperature recorded during the physical examination.
Torkelson (2002) reported that the formation of abscesses in this region results from the habit of uncastrated young horses to mount each other, which leads to anal penetration. This behavior is one of the causes to be taken into consideration, although the herein assessed model did not present history behavior consistent with this etiology. Hunt and Pouke (2008) and Gaddini et al. (2014), reported other cases whose causal agents could have been transrectal palpation, administration of intramuscular medication and muscular contusions. However, the horse assessed in the present case did not have history of subjection to such procedures. Palpation and transrectal ultrasonography are clinical practices capable of allowing the diagnosis of perirectal abscesses (Hunt and Pouke, 2008). These two diagnostic procedures could not be applied to the herein assessed model, because the edema in this region did not allow the examiner to introduce his/her hand in the rectum of the animal. Ultimate diagnosis was only possible post mortem. According to Barber (2008), this treatment consists in draining the abscess through a more ventral region and in systemic antibiotic therapy.

\section{Conclusion}

Given the impossibility of performing complementary tests and the early death of the assessed horse, the suspicion of small colon impaction was confirmed post mortem. This outcome evidenced the importance of necropsy in cases of colic syndrome without diagnosis in vivo. Accordingly, abscess diagnosis can be confirmed through transrectal palpation and ultrasonography, which enables abscess drainage and favorable prognosis. Colic causes are not easy to diagnose, so it is relevant reporting its occurrence in case of unusual etiologies, since such procedure would allow reliable and early diagnosis, and boost the development of these techniques.

\section{Conflict of Interest}

The authors report no conflicts of interest. The authors themselves are responsible for the content and writing of the manuscript.

\section{References}

Barber, S. Wound management of body and neck. In: Stashak, T. Equine wound management. $2^{\text {nd }}$ ed., Iowa: Wiley-Blackwell, 2008. p. 366367. 
Busoni, V.; De Busscher, V.; Lopez, D.; Verwilghen, D.; Cassart, D. Evaluation of a protocol for fast localised abdominal sonography of horses (FLASH) admitted for colic. Veterinary Journal, 188(1): 77-82, 2011.

Cook, V.L.; Hassel, D. Evaluation of the colic in horses: decision for referral. Veterinary Clinics of North American Equine Practitioners, 30(2): 383-398, 2014.

Dukti, S.; White, N.A. Prognosticating Equine Colic. Veterinary Clinics of Equine, 25(1): 217-231, 2009.

Ferreira, C.; Palhares, M.S.; Melo, U.P.; Gheller, V.A.; Braga, C.E. Cólicas por compactação em equinos: etiopatogenia, diagnóstico e tratamento. Acta Veterinaria Brasilica, 3(3): 117-126, 2009.

Gaddini, L.V.; Lorga, A.D.; Catussi, B.L.C.; Bortolato, J.S.D.; Meira, I.R.; Ferreira, A.G.G.; Rosado, R.; Borniotti, D.F.; Tomio, T.E.; Zavilenski, R.B.; Ribeiro, M.G. Ferida por aplicação de medicamento com agulha contaminada em equino. Revista de Ciências Veterinárias e Saúde Pública, 1(1): 1, 2014.

Hunt, L.; Pouch, S. Perirectal pyogranulomatous inflammation causing rectal obstruction and colic in a norwegian fjord gelding. Vlaams Diergeneeskd Tijdschr, 77(1): 26-28, 2008.

Massone, F. Considerações gerais. In: Anestesiologia veterinária: farmacologia e técnicas - texto e atlas. $6^{\mathrm{a}}$ ed. Rio de Janeiro: Guanabara Koogan, 2011. p. 1-10.

Pascoe, P.J.; McDonell, W.N.; Trim, C.M.; VanGorder, J. Mortality Rates and associated factors in equine colic operations - a retrospective study of 341 operations. Canadian Veterinary Journal, 24(3): 73-85, 1983.

Rakestraw, P.C.; Hardy. J. Large Intestine. In: Auer, J.A.; Stick, J.A. Equine Surgery, $3^{\text {th }} \mathrm{ed}$, Missouri: Elsevier, 2006. p. 435-478.

Southwood, L.L. Acute Abdomen. Clinical Technical of Equine Practice, 5(1): 112-126, 2006.

Torkelson, J. Perirectal abscess, colic, and dyschezia in a horse. Canadian Veterinary Journal, 43(2): 127-128, 2002.

White N.A.; Elward, A.; Moga, K.S.; Ward D.L.; Sampson, D.M. Use of web-based data collection to evaluate analgesic administration and the decision for surgery in horses with colic. Equine Veterinary Journal, 37(4): 347-350, 2005. 